\title{
The Exposure Effect of Water Pipe Smoke (WPS) on the Total Count leukocyte, Mitotic Index, Micronucleus Formation and Chromosome Aberration in Albino Male Mice

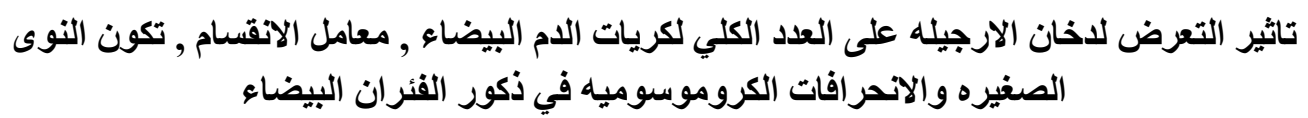

Mohammad M. F. Al-Halbosiy $\quad$ Rakad M. Kh. Al-Jumaily* $\quad$ Fadhel M. Lafta*

Biotechnology Research Center/ Al-Nahrain University

* College of Sciences/ University of Baghdad

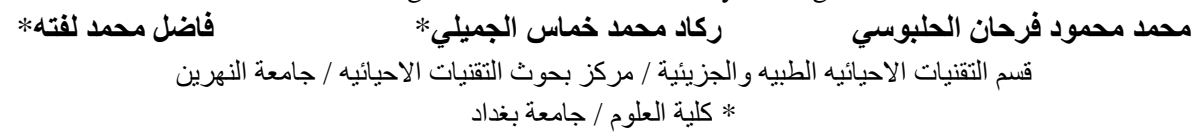

\begin{abstract}
The present study was carried out to evaluate the hematological and cytogenetic effects of water pipe smoke (WPS) in albino male mice. The investigated parameters were total count of leukocytes (TCL), mitotic index (MI), micronucleus (MN) formation and chromosomal aberrations. The results of our study showed that, mice were exposed to WPS using a special inhalation glass chamber (whole body exposure). Mice exposed daily to 100 puffs of WPS on the bases of (1h exposure per day). The exposure experiment continued daily for the periods of 3, 5, 7 weeks consequently. The results revealed that the TCL significantly decreased in the second and third treatment $(5930,4120 \mathrm{cell} / \mathrm{cu}$. $\mathrm{mm}$. blood) respectively, in comparison to control (6200 cell/ cu. mm. blood), while the MI decreased in all 3 treatment after 3, 5, 7 weeks. Nevertheless, both the MN cells and chromosomal aberration remain the same percentage as the control in the first treatment and then began to be higher than the control in the second and third treatment. The results indicated that the WPS has cytotoxic and mutagenic effects, according to the obtained results of $\mathrm{MN}$ cells and chromosomal aberration assays in the three types of treatment.
\end{abstract}

Key words: Water Pipe Smoke, Total Count Leukocyte, Mitotic Index, Micronucleus Formation, Chromosome Aberration, Mice.

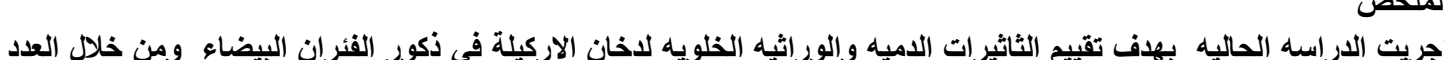

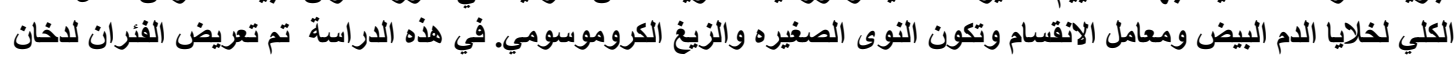

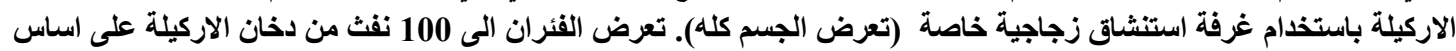

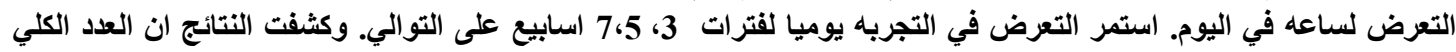

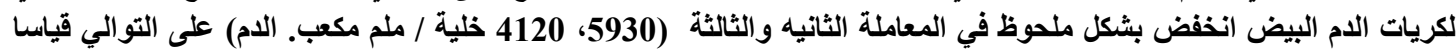

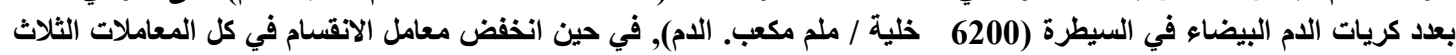

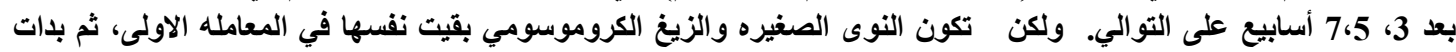

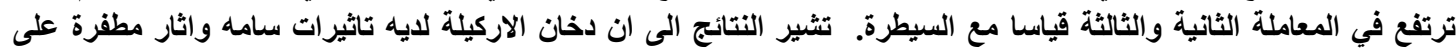
الخلايا اعتمادا على اختبارات الانويه الصغيره والزيغ الكروموسومي في المعاملات الثلاث.

الكلمات المفتاحية: دخان الاركيلة، العدد الكلي لخلايا الام البيض، معامل الانقسام، اختبرات الانوية، الزيغ الكروموسومي، الفارٔان

\section{Introduction}

Today, the public health officials are considered hookah (called narghile, shisha and water pipe in other parts of the world) smoking as a global threat and an epidemic [1, 2]. Especially, after sharp increase in popularity of the water pipe (wp) use in most European and Arabian countries [3]. Mistakenly, people believes that this smoking method is less harmful and addictive than cigarettes, meanwhile the observed during a water pipe session, indoor air contamination of different harmful substance is high and exposure may cause health risk for smokers [4]. Tobacco smoke aerosols, like all aerosols consist of gas phase and particulate. The gas phase contains volatile and semi-volatile compounds such as carbon monoxide (Co), nitrogen, nitric oxide, hydrogen cyanide, and a small proportion of the nicotine, delivered to smoker and the particulate phase, consisting primarily of condensed liquid droplets in capable scattering light and give tobacco smoke it s visible character [5]. 
Tobacco smoke contains over 4800 different chemicals out of which 69 are carcinogens and several are carcinogens or tumor promoters [6]. According to studies conducted by researchers at the American university of Beirut, the Water Pipe Smoke (WPS) contains a significant quantities of the same chemicals which make cigarette smoke harmful [7]. The analysis of the smoke from the primary flow of WP, the results show significant quantities of nicotine, Tar , and heavy metals, as well as bonzopyrene, nickel, arsenic, cobalt, beryllium, chromium and lead all in large quantities than those found in cigarette smoke [8].

In WPS the uptake of tobacco nicotine is equivalent to 2-12 cigarettes per portion of tobacco used [9]. While a single 100 puff of WPS session produces as much Tar as 20 or more than cigarettes. [10]. Moreover a single WPS session yields 20 times the amount of polycyclic aromatic hydrocarbons found in main stream cigarette as well as acetaldehyde, formaldehyde, and acrolein [11].

The nicotine content is estimated at 2-4\%, in WP compared with 1-3\% for tobacco used in cigarettes [8]. According to a study of carbon monoxide in cigarette smoke and WP, the carbon monoxide concentration were $0.34 \%$ to $1.40 \%$ for WPS while cigarette smoke concentration were $0.41 \%$. The carbon monoxide concentration in WPS was significantly greater for smaller WP size and for commercial as opposed to domestic charcoal [12].

A recent study involving machine smoking show that carbon monoxide (Co) concentrates in WP main stream smoke, is up to 13 time inferior than in cigarette $1.79 \mathrm{mg}$ for $1000 \mathrm{ml} \mathrm{WP}$ (machine) puff and $1.06 \mathrm{mg}$ for a $45 \mathrm{ml}$ cigarette puff [13]. Whereby, a research on health effects of WPS revealed that WP smokers may inhale larger amounts of smoke than cigarette smokers during a single smoking session $[14,15]$.

Long term exposure to compounds found in WPS responsible for pulmonary damages and lose of elasticity in the alveoli, leading to emphysema [16]. Furthermore, WPS appear to be associated with lung cancer, low birth weight in babies and respiratory diseases [15]. Changes measured in the amount of air moved in and out of the lungs when smokers breathe suggest that WPS and cigarette smoking have similar effects on person breathing [17].

The aims of current study was to investigate the risk of WPS and their carcinogens effects.

\section{Material and Method:}

Albino male mice (Mus musculus) of age 9-10 week used for this study, which was carried out on laboratory, temperature was maintained at $25{ }^{\circ} \mathrm{C}$ and light/dark was set at $12 \mathrm{hr}$ intervals. Water and food were available ad-libitum, except during inhalation exposure.

According to the specification of WHO, Body inhalation exposure was carried out by using a made glass chamber figure (1), designed as a static system [18,19].

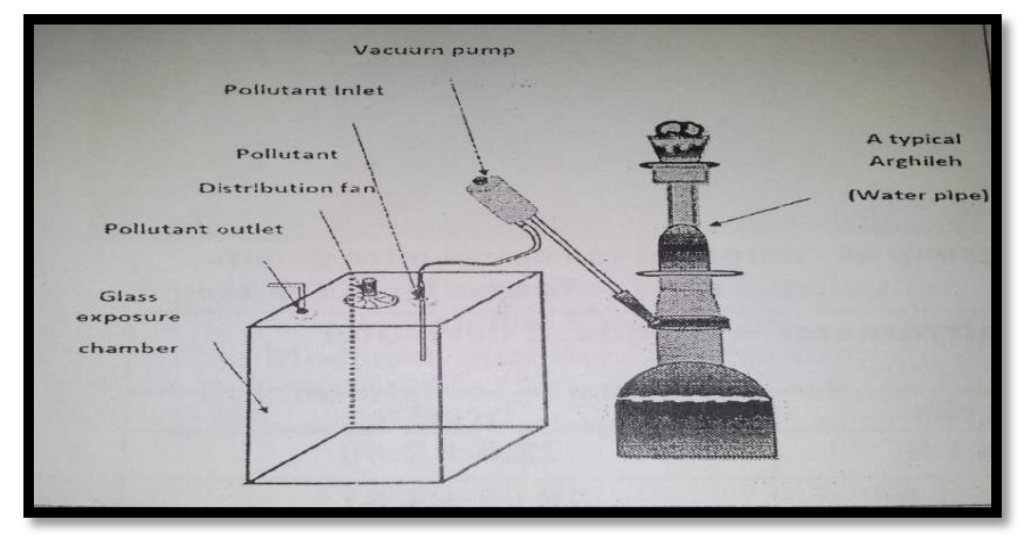

Fig. (1): Inhalation Exposure Chamber

Inhalation exposure chamber commercial "Muesslel"or Ma'assel, flavored with strawberry (Arabic origin), were used. It's composed of approximately 70\% Honey or Molasses and 30\% Tobacco. Daily, WPS was generated by burning $2 \mathrm{gm}$ of " Ma'assel " using a commercial charcoal and introduced as puffs into the chamber, each puff capacity is $50 \mathrm{cc} / 2 \mathrm{sec}$, using a manual vacuum pump.

The exposure operation took $1 \mathrm{hr} /$ day for 3, 5, 7 week consequently, whereby mice exposed to 100 puffs /day, one puff /2sec. 
The control group animals $(n=9)$, exposed to fresh air only and they followed the same system. Animal's kept together during exposure, labeling was helpful to carry out this operation in order to avoid any confusion that could happen during the experiment.

The animals were investigated for the following parameters: total count leucocyte, mitotic index, micronucleus formation and chromosomal aberration. Total count leucocyte (TCL) was performed on blood obtain from the tail of animals using the conventional method of blood cell count [20, 21]. The mitotic index (MI) and chromosomal aberration (CA) were assessed in the bone marrow cell after injection the animals with colchicine [22,23]. The micronucleus formation was examined in bone marrow cells that were obtained from the femur of animals [24, 25], and it is worth to mention that these animals (that used to micronucleus assay) were not treated with colchicine.

\section{Statistical Analysis}

Differences between means were assessed by the least significant difference (LCD) using SPSS.

\section{Results}

In the first treatment after 3 weeks the total count leucocyte (TCL) was increased but in small amount compared with control group. In addition, the Mitotic Index count was decreased (non-significantly) compared to the control. Meanwhile, no increase were found in the other parameters Table (1).

In the second treatment after 5 weeks both the TCL and Mitotic index (MI) were decreased compared to the control. In contrast, the count of both micronucleus cells and chromosomal aberration were increased in the third treatments after 7 weeks Similar to the second treatment, a decrease was recorded in the TCL and Mitotic index (MI). Meanwhile we have found an increase in the count of both micronucleus cells and chromosomal aberration.

Table (1): The effect of WPS on total count leukocyte, mitotic index, micronucleus formation and chromosomal aberration in Albino mal mice.

\begin{tabular}{|c|c|c|c|c|}
\hline \multirow{2}{*}{$\begin{array}{c}\text { Parameters } \\
\text { Groups }\end{array}$} & \multicolumn{4}{|c|}{ Mean \pm Standard Deviation } \\
\hline & $\begin{array}{c}\text { TCL }^{* *}{ }^{*} \times 10^{3} \\
\text { (cells/cu.mm.blood) }\end{array}$ & $\begin{array}{c}\text { Mitotic Index } \\
(\%)\end{array}$ & $\begin{array}{l}\text { Micronucleus } \\
\text { Index }(\%)\end{array}$ & $\begin{array}{c}\text { Chromosomal } \\
\text { Aberrations (\%) }\end{array}$ \\
\hline Control & $6200 \pm 254.95$ & $10.76 \pm 0.23$ & 0.0 & 0.0 \\
\hline Treatment 1,3 week & $6360 \pm 350.14$ & $10.34 \pm 0.19$ & 0.0 & 0.0 \\
\hline Treatment 2,5 week & $5930 \pm 152.15^{*}$ & $9.76 \pm 0.23^{*}$ & $3.92 \pm 0.39 *$ & $1.46 \pm 0.23^{*}$ \\
\hline Treatment 3,7 week & $4120 \pm 138.38 *$ & $7.06 \pm 0.86^{*}$ & $6.48 \pm 0.24^{*}$ & $4.46 \pm 0.58^{*}$ \\
\hline
\end{tabular}

* Significant difference from control $(\mathbf{p} \leq \mathbf{0 . 0 5})$

* * TCL $=$ Total Count Leukocyte

The results of first treatment revealed that the TCL were non-significant $(p \leq 0.05)$ increased.

Meanwhile we have recorded a significant decreased in the second and third treatment $(\mathrm{p} \leq 0.05)$,

respectively.

The Mitotic index was decreased in all treatments $10.34,9.76,7.06 \%$ respectively in compare to the control group $10.76 \%$. While there were no changes recorded for the micronucleus cells and chromosomal aberration in the first treatment.

\section{Discussion}

The results of the treatments showed that the TCL were increased after first treatment only, while it decreased in the other treatments. Mitotic index were decreased in all treatments while both the micronucleus cells and chromosomal aberration were decreased only after first treatment and increased in the second and third treatment respectively.

The results indicated that the WPS has cytotoxic and mutagenic effects, depended on the findings of micronucleus cells and chromosomal aberration assays in the three types of treatment. A support of such results has been presented by Hoffmann, who demonstrated that the WPS is toxic and has genotoxic effects [6].

The chemistry of the WPS compounds and their biological effects has been the potential of an intensive researches, and therefore the observed effects can be explained in terms of the chemical constituents. According to WHO [9], the long term exposure to compounds found in WPS such as: Cyanide, Carbon monoxide, responsible for pulmonary damages and lose of elasticity in the alveoli, leading to emphysema [16]. Furthermore, the usage of WPS increased the risk of bronchogenic carcinoma as well as lung [26]. Four studies were done on Mice and Rats, found that exposure to whole tobacco smoke lead to increase in the occurrence of malignant and/or benign lung tumors [27]. 
In addition, WPS contains carcinogens such as polycyclic aromatic hydrocarbons [28], and water pipe extract produces degeneration and hyperkeratosis in rat mucosa [29]. Moreover, in other study representing in comparing 35 healthy water pipe users with 35 healthy, non exposed controls, the use of water pipe was associated with a significant increase in frequency of sister chromatid exchanges and chromosomal aberration[30].

In conclusion, water pipe smoking has not been studies as intensively as has cigarette smoking. However, the preliminary research on patterns of smoking, the chemistry of the smoke that is inhaled, and health effects supports the idea that WPS is associated with many of the same or more risks as cigarette smoking, and may involve some unique health risk.

\section{References}

1. Souri, H. (2002). Patterns of smoking among adults in the city of Ahwaz. Journal of Medical Council of I.R.I. 20:28-32.

2. Wen, C.P., Tsai S.P., Cheng T.Y., Chan H.T., Chung W.S., Chen C.J. (2005). Excess injurymortality among smokers: a neglected tobacco hazard. Tob. Control., Suppl. 1:i28-32.

3. AL-Numair, K., Barber - Heidal, K., AL-Assa, A., and EL-Desoky G. (2007). Water pipe (shisha) smoking influences total antioxidant capacity and oxidative stress of healthy Saudi males. Food Agricul. Environ. 5:17-22.

4. Fromine, H., Dietrich S., Heitmann D., Dressel H., Diemer J., Schulz T., Jorres R.A., Berlin K., and Volkel W. (2009). Indoor air contamination during a water pipe (narghile) smoking session. Food and Chemical Toxilogical. 47(7):1636-1641.

5. Eissenberg, T., Ward, K.D., Smith-Simone, S., Maziak, W. (2008). Water pipe tobacco smoking on a U.S. College campus: prevalence and correlates. J Adolesc. Health. 42(5):526-529.

6. Hoffmann, D.C., Patrianakos, K.D., Brunnemann, and Gori, G.B. (1976). Chromatographic determination of vinyl chloride in tobacco smoke. Anal. Chem. 48, 47-50.

7. Jabbour, S., Geahchan, N., Harfouch, S., Saae, G., and Shihadeh, A. (2003). New research: narghile smokers exposed to dangerous chemical. Food and Toxolog. 18: 49-52.

8. Shihadeh, A., Saleh, R. (2005). Polycyclic aromatic hydrocarbons, carbon monoxide, "tar', and nicotine in the mainstream smoke aerosol of thenarghile water pipe. Food and Chem. Toxicol. 43(5):655-661.

9. WHO. (2006). Tobacco use in Shisha: studies on water pipe smoking in Egypt. Center of Tobacco Control Research and Education. Cairo, Egypt: WHO Regional Office for the Eastern Mediterranean.

10.Pankow, J.F. (2001). A consideration of the role of gas/ particle partitioning in the deposition of nicotine and other tobacco smoke compounds in the respiratory tract. Chem. Res. Toxicol. 14: 14651481.

11.Sepetdjian, E., Shihadeh, A., and Saliba, N.A. (2008). Measurement of 16 polycyclic aromatic hydrocarbons in narghile water pipe tobacco smoking. Food Chem. Toxicol. 46:1582- 1590.

12. Barry, K., and Yono, A. (2005). Water-Pipe (Narghile) Smoking: An Emerging Health Risk Behavior. Pediatrics. Vol. 116 No. 1: 113-119.

13. Monn, C., Kinderdler, P., Meile, A., Brandli, O. (2007). Ultrafine particle emissions from water pipe. Tob. Control. 16: 390-393.

14.Maziak, W. (2011). The global epidemic of water pipe smoking. Addictive behavior. 36:1-5. doi: 10.1016/j.addbeh.

15.Elie, A.A., Swarna, G., Samee,r K. (2010). The effect of water pipe tobacco smoking on health outcomes: A systimatic Review. Int J. Epidemiol. 39: 834-857.

16. Shafagoj, Y.A., and Mohammed, F. (2002). Levels of maximum end-expiratory carbon monoxide and certain cardiovascular parameters following Hubble - bubble smoking. Saudi Med. J. 23: 953 - 958.

17.Chan, A. (2011). The fallacy of the harmless hookah. Nicotine Tob. Res. 139:737-738.

18.WHO. (1978). Principles and method of evaluating the toxicity of chemical part.

19.Hinners, R.G. (1966). Animal exposure chamber. Arch. Environ. Health. 13: 609-615.

20. Sood, R. (1985). Heamatology for student and practitioners. Jaypee Brothers Medical Publishers (P) Ltd, New Delhi India. PP: 686.

21.Hudson, L. and Hay, F.C. (1990). Practical immunology. 2nd ed., Black Well Scientific Publication, U. K. chap. 6, pp. 180.

22. Stich, M. and San, C. (1981). Topics in environmental physiology and medicine in short-term tests and chemical carcinogens. Springer Vuglgare. New York. PP.31:53.

23. Shubber, E.K. and Al-Allak, B.M.A. (1986). Spontaneous frequencies of chromosome aberration and sister chromatid exchange in human lymphocytes. II. Effect of serum incubation time and blood Storage. Nucleus. 30: 21-28. 
24.Schmid, W. (1976). The cell micronucleus test for cytogenetic analysis. In: Hollaender, A. (Ed). Chemical Mutagens: Principles and Methods for their Detection,vol.4. Plenum Press, New York and London. pp.31:53.

25. Fenech, M. (1993). Mouse and human micronucleus models for assessing genotoxicity of whole food in intervention studies. Mutat. Res. 290: 119-125.

26. Maziak, W., Ward, K.D., Afifi Soweid, R.A. and Eisserberg, T. (2004). Tobacco smoking using a water pipe: a re-emerging strain in a global epidemic. Tobacco control. 13: 327-333.

27.WHO. (2002). Tobacco Smoke and Involuntary Smoking. Vol.83.

28. Abbas, E., Abou-Azma, N., Bulus, S. (2003). Effect of Goza smoking on rat's oral mucosa. Egyptian J. Histol. 10: 156.

29. Shihadeh, A. (2003). Investigation of mainstream smoke aerosol of the argileh water pipe. Food Chem Toxicol. 41:143-152.

30. Yadav, J.S., Thakur, S. (2000). Genetic risk assessment in hookah smokers. Cytobios. 101: 101-113. 